\title{
Summary of an Ongoing Population Study of PARNASSIUS CLODIUS BUTTERFLIES
}

\author{
JiLl A. SHERWOOD $\downarrow$ DiANE M. DEBINSKI $\downarrow$ DEPARTMENT OF ECOLOGY, EVOLUTION AND \\ ORGANISMAL BIOLOGY $\downarrow$ IOWA STATE UNIVERSITY $\downarrow$ AMES
}

\begin{abstract}
$\uparrow \quad$ ABSTRACT
Global and regional climate patterns suggest that future conditions in the western United States will be warmer and drier. Changing climatic conditions are predicted to impact ecosystems on many levels including at a population level. Decreases in population distribution and sizes have the potential to disrupt community and species diversity. Insects are particularly useful organisms to study because of their shorter life spans and sensitivity to changes environmental conditions. We expanded on previous population studies of a butterfly species, Parnassius clodius, located in Grand Teton National Park using mark-recapture techniques. We collected data to assess population size and sex ration on one particular population located in the park. Using mark-recapture techniques, we were able to collect data to assess population numbers, total number of males and females, sex rations and number of mated versus unmated females throughout the flight season. Here we compiled information about this population to provide benchmark information for this species and its population dynamics. The combined population data will be further used to study how changing climatic conditions have affected this population throughout the study years. The results will be valuable for understanding the population and also for understanding potential climate-related impacts on butterfly populations in other locations.
\end{abstract}

\section{$\downarrow \quad$ INTRODUCTION}

Global and regional climate patterns suggest that future conditions in the western U.S. will be warmer and drier, and ecosystems at higher altitudes and latitudes may be subject to larger, more rapid changes (Harte and Shaw 1995; Thuiller et al. 2005). As a result of increasing temperatures and decreasing winter precipitation, it is predicted that the duration of snow cover will decrease (IPCC 2007). Such changes have the potential to impact the dynamic interactions among organisms and their habitat (Bradley et al. 1999; Folke et al. 2004). Climatic changes are predicted to alter species distributions, life histories, community composition, and ecosystem function that cascade through the ecosystem because of the complex interplay of organisms (i.e. Kudo 1992; Dunne et al. 2003; Parmesan and Yohe 2003; Inouye 2008). In particular, changes in population sizes, as a result of changing climate conditions, have the potential to decrease community and species diversity (Root et al. 2003). Evidence from various studies indicates that range shifting in response to climate warming may lead to population extinctions (i.e. Walther et al. 2002; Parmesan 2006). One particular group of organisms that serves as a useful indicator of climate change effects is insects because they are short-lived ectotherms with wide variation in population size over space and time (Bale et al. 2002; Maclean and Wilson 2010).

Insects have provided clear evidence for ecological responses to climate change. Examination of populations in Europe and North America reveal that butterfly distributions are shifting poleward (Parmesan and Yohe 2003; Parmesan 2006), and phenological events, such as emergence and spring activity, are advancing to earlier spring dates as a result of climate warming (Roy and Sparks 2000; Peñuelas et al. 2002; Stefanescu et al. 2003). Given the greater availability of both current and historical information on species distributions and population sizes, 
Lepidoptera can play a key role in providing evidence and further understanding climate change.

Parnassius clodius is a common butterfly in the Greater Yellowstone Ecosystem. However, two related European species, Parnassius mnemosyne and Parnassius apollo are considered to be vulnerable throughout much of their European range as populations have undergone substantial decline and extinction due primarily to habitat change and climate change (Van Swaay and Warren, 1999; Bergström 2005; Descimon et al. 2005; Nakonieczny et al. 2007; Ashton et al. 2009; Gorbach and Kabanen 2010). Utilizing data obtained from population studies on a common species, we may be able to inform ecologists and land managers as to what factors play a role in population stability.

This study, begun in 2009, was established to provide more information on population dynamics of one of the largest populations of Parnassius clodius in Grand Teton National Park by expanding on previous studies from 1999-2001. We collected data using mark-recapture techniques to assess population dynamics, such as population size and sex ratio. Here we compile information obtained from population studies and observations of $P$. clodius from 2009-2012. Our goal is to provide a benchmark of information on this species and its population dynamics for future studies that may utilize the same sites.

\section{$\uparrow \quad$ METHODS}

\section{Study Organism}

$P$. clodius are moderately large in size (wingspan of $5-7$ centimeters), predominantly white butterflies found in western Canada and the western United States. Highest densities of $P$. clodius are typically found in dry, gravelly sagebrush meadows (Auckland et al. 2004). P. clodius adults have one flight per year from mid-June to mid-July. Adult females lay eggs on vegetation near the host plant species, Dicentra uniflora. D. uniflora is a spring ephemeral that is found growing near the edges of snowmelt (Craighead et al. 1998). P. clodius larvae feed on the host plant throughout the spring until pupation. Adults display virtually no evidence of courtship behavior. Rather, patrolling males grab females in flight and force them to the ground to copulate (McCorkle and Hammond 1985).

\section{Study Sites}

A mark-recapture-release (MRR) study of a
P. clodius population was conducted in a dry, sagebrush meadow with a relatively homogeneous topography at an elevation of 2100 meters located within Grand Teton National Park, WY. The meadow is approximately $2 \times 0.5 \mathrm{~km}$ in size (Auckland et al. 2004) and located along Pilgrim Creek Road, just south of the University of Wyoming-National Park Service Research Station. Based on previous studies, we concluded that the Pilgrim Creek population is one of the larger populations of $P$. clodius within the Greater Yellowstone Ecosystem. Thus there were sufficient numbers (e.g., hundreds) of butterflies present annually for a mark-recapture-release study (Auckland et al. 2004).

\section{Mark-recapture-release (MRR) study}

Adult population size was investigated during the annual flight period in summer months from 2009 - 2012. For each year, MRR studies were initiated immediately after adult emergence and were terminated when less than 5 butterflies were seen summed across all of the plots, signaling population decline. Daily surveys were limited to times between 10:00 and 17:00 hours, and when the temperature was above $21^{\circ} \mathrm{C}$, wind was $<16 \mathrm{kmh}^{-1}$, and the sun was not obscured by clouds. When conditions did not meet the above requirements, MRR surveys were not performed. However, during all four summers, the majority of the days during the flight season were adequate for MRR. Using MRR technique, two investigators walked within 50 x 50 meters plots (located approximately 200 meters apart) for 20 minutes and captured any $P$. clodius individual within the boundary of the plot using a butterfly net. Individuals were then placed in glassine envelopes and held by the investigator in a small box attached to a belt until the end of the survey. At the end of the survey time, surveyors moved off of the plot to a shady location to process the butterflies caught and record data. All unmarked captured individuals were marked with unique numbers, indicating the plot in which they were caught, on the ventral side of each hindwing, using a felt-tip permanent marker. Information for previously marked individuals was recorded, including the plot number where the individual was captured. Males and females were identified based on external morphological differences. Female mating status was determined by the presence or absence of a sphragus (a waxy structure deposited by the male during mating that prevents future matings). Wing wear of each captured butterfly was recorded for each butterfly. Wing wear classification was as follows: 1) good conditions, no visible damage, 2) slightly damaged wings, small tears, 3) heavily damaged wings or missing wings. Behavior at the time of 
sighting (in flight, nectaring (and plant species upon which it was nectaring), or basking/resting (type of surface)) was also recorded. After all the information was recorded for the captured individuals within that plot ( 30. min or less), butterflies were released from the center of the plot. It is also important to note that there were generally less than two mortalities per year of all butterflies captured as a result of capture and handling. We randomly surveyed the plots starting with a successive number the following day in order to sample at different times of day for each plot.

\section{$\uparrow \quad$ RESULTS}

Initially, six 50 x 50 plots (plots $1-6$ ) were surveyed in 2009. Due to a separate but related experiment in the meadow, plot 4 was removed from surveys after the 2009 field season. The original five plots $(1-3 ; 5-6)$ were surveyed in 2010. Plot 2 was not surveyed in 2011 due to bear presence. However, two additional plots ( $7 \mathrm{a}$ and 8 ) were added to the 2011 surveys. In 2012, the original plots $(1-3 ; 5-6)$ were surveyed with an additional plot (7b). Table 1 lists the locations (UTM - zone 12N) for each of the plots surveyed and the years in which they were surveyed.
In all years, males were captured more frequently than females (Table 2). Based on the number of plots surveyed, the average number of males that were captured per plot ranged from 141 to 33 individuals, while the average number of females per plot ranged from 35 to 9 . The capture sex ratio males/females also varied from year to year with the highest ratio occurring in 2009 with 4 males to 1 female. The lowest sex ratio of males/females occurred in 2012 with 2 males to 1 female.

Annual flight periods varied among years (Table 3). The earliest date of male emergence occurred in 2012 when males emerged on June $13^{\text {th }}$. In 2011, males were not seen until July 6th. In general, females emerged after males, ranging from $1-7$ days after the first males were seen. This resulted in a later peak flight time for females when compared with males. Females also stayed on the wing slightly longer than males.

Average wing-wear condition showed a steady increase as the flight season progressed. Males showed slightly greater wing wear overall when compared with females. Also, as one might expect due to the forceful nature of copulation in this species, mated females had greater wing wear than unmated females.

Table 1. Summary of UTM coordinates for plots surveyed and years surveyed (UTM NAD 1983 zone 12N).

\begin{tabular}{|c|c|c|c|c|c|}
\hline Plot \# & Northeast Corner & Southeast Corner & Southwest Corner & Northwest Corner & $\begin{array}{c}\text { Years } \\
\text { Surveyed }\end{array}$ \\
\hline 1 & $\begin{array}{l}\text { E0534108 } \\
\text { N4862885 }\end{array}$ & $\begin{array}{l}\text { E0534099 } \\
\text { N4862833 } \\
\end{array}$ & $\begin{array}{l}\text { E0534051 } \\
\text { N4862845 } \\
\end{array}$ & $\begin{array}{l}\text { E0534059 } \\
\text { N4862886 }\end{array}$ & $2009-2012$ \\
\hline 2 & $\begin{array}{c}\text { E0533907 } \\
\text { N4862808 } \\
\end{array}$ & $\begin{array}{l}\text { E0533902 } \\
\text { N4862755 }\end{array}$ & $\begin{array}{l}\text { E0533847 } \\
\text { N4862765 }\end{array}$ & $\begin{array}{l}\text { E0533860 } \\
\text { N4862808 }\end{array}$ & $\begin{array}{c}2009-2010 \\
2012\end{array}$ \\
\hline 3 & $\begin{array}{l}\text { E0533812 } \\
\text { N4862642 } \\
\end{array}$ & $\begin{array}{l}\text { E0533801 } \\
\text { N4862579 } \\
\end{array}$ & $\begin{array}{l}\text { E0533751 } \\
\text { N4862602 } \\
\end{array}$ & $\begin{array}{l}\text { E0533760 } \\
\text { N4862649 } \\
\end{array}$ & $2009-2012$ \\
\hline 4 & $\begin{array}{r}\text { E0533917 } \\
\text { N4862535 } \\
\end{array}$ & $\begin{array}{r}\text { E0533924 } \\
\text { N4862525 } \\
\end{array}$ & $\begin{array}{r}\text { E0533872 } \\
\text { N4862471 } \\
\end{array}$ & $\begin{array}{r}\text { E0533850 } \\
\text { N4862503 } \\
\end{array}$ & 2009 \\
\hline 5 & $\begin{array}{l}\text { E0533717 } \\
\text { N4862409 }\end{array}$ & $\begin{array}{l}\text { E0533750 } \\
\text { N4862373 }\end{array}$ & $\begin{array}{c}\text { E0533704 } \\
\text { N4862346 }\end{array}$ & $\begin{array}{l}\text { E0533678 } \\
\text { N4862387 }\end{array}$ & $2009-2012$ \\
\hline 6 & $\begin{array}{l}\text { E0533629 } \\
\text { N4862510 }\end{array}$ & $\begin{array}{l}\text { E } 0533622 \\
\text { N4862458 }\end{array}$ & $\begin{array}{l}\text { E } 0533573 \\
\text { N4862465 }\end{array}$ & $\begin{array}{c}\text { E05337578 } \\
\text { N4862519 }\end{array}$ & $2009-2012$ \\
\hline $7 \mathrm{a}$ & $\begin{array}{r}\text { E0533488 } \\
\text { N4862389 } \\
\end{array}$ & $\begin{array}{r}\text { E0533421 } \\
\text { N4862369 } \\
\end{array}$ & $\begin{array}{l}\text { E0533442 } \\
\text { N4862415 } \\
\end{array}$ & $\begin{array}{l}\text { E0533488 } \\
\text { N4862389 } \\
\end{array}$ & 2011 \\
\hline $7 b$ & $\begin{array}{l}\text { E0533614 } \\
\text { N4862181 }\end{array}$ & $\begin{array}{l}\text { E0533604 } \\
\text { N4862131 }\end{array}$ & $\begin{array}{l}\text { E0533552 } \\
\text { N4862140 }\end{array}$ & $\begin{array}{l}\text { E0533561 } \\
\text { N4862192 }\end{array}$ & 2012 \\
\hline 8 & $\begin{array}{l}\text { E0533582 } \\
\text { N4862292 }\end{array}$ & $\begin{array}{l}\text { E0533622 } \\
\text { N4862254 }\end{array}$ & $\begin{array}{l}\text { E0533581 } \\
\text { N4862219 }\end{array}$ & $\begin{array}{l}\text { E0533547 } \\
\text { N4862256 }\end{array}$ & 2011 \\
\hline
\end{tabular}


Table 2. Summary of number of plots surveyed per year, average number of males and females per plot by year and ratio of males to females captured.

\begin{tabular}{|c|c|c|c|c|}
\hline Year & $\begin{array}{c}\text { \# of plots } \\
\text { surveyed }\end{array}$ & Ave. \# males/plot & $\begin{array}{c}\text { Ave. \# } \\
\text { females/plot }\end{array}$ & $\begin{array}{c}\text { Ratio of } \\
\text { male/female }\end{array}$ \\
\hline 2009 & 6 & 141.14 & 34.83 & 4.05 \\
2010 & 5 & 45.80 & 12.80 & 3.58 \\
2011 & 7 & 32.71 & 9.29 & 3.52 \\
2012 & 6 & 56.00 & 27.00 & 2.07 \\
\hline
\end{tabular}

Table 3. Summary of emergence dates for males and females by year and last date sampled by year.

\begin{tabular}{|c|c|c|c|}
\hline Year & Male Emergence Date & Female Emergence Date & Last Date Sampled \\
\hline 2009 & 24-Jun & 25-Jun & 12-Jul \\
\hline 2010 & 4-Jul & 6-Jul & 15-Jul \\
\hline 2011 & 6-Jul & 7-Jul & 3-Jul \\
\hline 2012 & 13-Jun & 20-Jun \\
\hline
\end{tabular}

\section{$\downarrow \quad$ CONCLUSIONS}

Our MRR study has resulted in a large dataset that contains a great deal of information on Parnassius clodius butterflies. Throughout the course of data collection, we were able to collect data on many variables that relate to population dynamics in $P$. clodius, such as emergence dates for males and females, peak flight dates for both sexes, wing wear throughout the season, and mating status. Each of these factors varied throughout the years the study was conducted. This report summarizes some of the information obtained from these studies. Future analyses will be performed to uncover potential reasons for variations in population sizes and emergence dates and to correlate these responses to annual weather patterns.

\section{$\uparrow \quad$ ACKNOWLEDGEMENTS}

This research was supported by grants from the Xerces Society, the Center for Global and Regional Environmental Research, and University of Wyoming National Park Service Research Station. The authors would like to thank to everyone who assisted with the mark-recapture-release studies throughout the years: David Nelson, Sharon Bird, Calla Ward Olson, Maggie Jordan, Melissa Kyer, Annie Binder, Susan Cable, Lauren Miller, Kim Szcodronski and Zoe Pritchard. And, a very special thanks goes to Kelly McCloskey for her help in navigating the park system.

\section{LITERATURE CiTED}

Ashton S, Gutiérrez D, Wilson RD. 2009. Effects of temperature and elevation on habitat use by a rare mountain butterfly: implications for species responses to climate change. Ecological Entomology 34: 437 - 446.

Auckland JN, Debinski DM, Clark WR. 2004. Survival, movement and resource use of the butterfly Parnassius clodius. Ecological Entomology 29: $139-149$.

Bale JS, Masters GJ, Hodkinson ID, Awmack C, Bezemer M, Brown TM, Butterfield VK, Buse J, Coulson A, Farrar JC, Good J, Harrington JEG, Hartley R, Jones S, Lindroth TH, Press RL, Symrnioudis MC, Watt I, Whittaker WB. 2002. Herbivory in global climate change research: direct effects of rising temperatures on insect herbivores. Global Change Biology 8:1 - 16.

Bergström A. 2005. Oviposition site preferences of the threatened butterfly Parnassius mnemosyne implications for conservation. Journal of Insect Conservation 9: $21-27$.

Bradley NL, Leopold AC, Ross J, Huffaker W. 1999. Phenological changes reflect climate change in Wisconsin. Proceedings of the National Academy of Sciences of the USA, 96: 97019704. 
Craighead JJ, Craighead FC Jr, Davis RJ. 1998. A Field Guide to Rocky Mountain Wildflowers. Houghton Mifflin Co., New York.

Descimon H, Bachelard P, Boitier E, V Pierrat. 2005. Decline and extinction of Parnassius apollo populations in France-continued. In: Kühn E, Feldmann R, Thomas JA, Settele J, editors.. Studies on the Ecology and Conservation of Butterfl ies in Europe. Vol. 1: General Concepts and Case Studies. p . 114 - 115. Sofia: Pensoft, Sofia-.

Dunne JA, Harte J, Taylor KJ. 2003. Subalpine meadow flowering phenology responses to climate change: integrating experimental and gradient methods. Ecological Monographs 73: 69-86.

Folke C, Carpenter S, Walker B, Scheffer M, Elmqvist T, Gunderson L, Holling CS. 2004. Regime shifts, resilience, and biodiversity in ecosystem management. Annual Review of Ecology Evolution and Systematics 35: 557-581.

Gorbach VV, Kabanen DN. 2010. Spatial organization of the clouded Apollo population (Parnassius mnemosyne) in Onega Lake Basin. Entomological Review 90(1): $11-22$.

Harte J, Shaw R. 1995. Shifting dominance within a montane vegetation community - results of a climate-warming experiment. Science. 267: 876-880.

Inouye, DW. 2008. Effects of climate change on phenology, frost damage, and floral abundance of montane wildflowers. Ecology. 89:353-362.

IPCC, editors. 2007. IPCC Fourth Assessment Report: Climate Change 2007 - The AR4 Synthesis report. A contribution of Working Groups I, II, and III to the Fourth Assessment Report of the Intergovernmental Panel on Climate Change. Core Writing Team, Pachauri, R.K. and Reisinger, A, editors. IPCC, Geneva, Switzerland. pp 104.

Kudo G. 1992. Performance and phenology of alpine herbs along a snow-melting gradient. Ecological Research 7: 297-304.

McCorkle DV, Hammond PC. 1985. Observations on the Biology of the Parnassius clodius
(Papilionidae) in the Pacific Northwest. Journal Lepidopterists' Society. 39: 156 - 162.

Maclean, M.D. and R.J. Wilson. 2010. Recent ecological responses to climate change support predictions of high extinction risk. Proceedings of the National Academy of Sciences. 108: 12337-12342.

Nakonieczny M, Kedziorski A, Michalczyk K. 2007. Apollo butterfly (Parnassius apollo L.) in Europe: its history, decline and perspectives of conservation. Functional Ecosystems and Communities 1: 56-79.

Parmesan C, Yohe G. 2003. A globally coherent fingerprint of climate change impacts across natural systems. Nature 421:37-42.

Parmesan C. 2006. Ecological and evolutionary responses to recent climate change. Annual Review of Ecology, Evolution, and Systematics. 37: $637-669$.

Peñuelas J, Filella I, Comas P. 2002. Changed plant and animal life cycles from 1952 to 2000 in the Mediterranean region. Global Change Biology, 8: 531-544.

Root TL, Price JT, Hall KR, Schneider SH, Rosenweig C, Pounds JA. 2003. Fingerprints of global warming on wild animals and plants. Nature 421:57-60

Roy DB, TH Sparks. 2000. Phenology of British butterflies and climate change. Global Change Biology 6, 407-416.

Stefanescu C, Peñuelas J, I Filella. 2003. Effects of climatic change on the phenology of butterflies in the northwest Mediterranean Basin. Global Change Biology 9: 1494-1506.

Thuiller W, Lavorel S, Araujo MB, Sykes MT, Prentice IC. 2005. Climate change threats to plant diversity in Europe. Proceedings of the National Academy of Sciences. 102:8245 8250 .

Van Swaay CAM, Warren MS. 1999. Red Data Book of European Butterflies (Rhopalocera). Nature 
and Environment No. 99, Council of Europe Publishing, Strasbourg.

Walther GR, Post E, Convey P, Menzel A, Parmesan C, Beebee TJC, Fromentin JM, Hoegh-Guldberg O, Bairlein F. 2002. Ecological responses to recent climate change. Nature 416:389-395. 